\title{
Clientele's Predisposition Towards Phantom Brands - An Indian Perspective
}

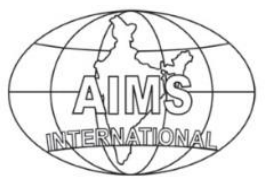

DOI: $10.26573 / 2021.15 .2 .3$

Volume 15, Number 2

May 2021, pp. 101-117

\author{
M. Beulah Viji Christiana \\ Panimalar Engineering College \\ (beulah_christiana@yahoo.co.in) \\ M. Joseph Sasi Rajan \\ Fujitsu Consulting India Private Ltd \\ (joseph.sasirm@gmail.com)
}

Today's highly competitive and dynamic environment that prevails in the Indian scenario has given opportunity for the emergence of Private Label Brands also termed as Phantom Brands. These brands are created and owned by powerful retailers and the power of such phantom brands largely depends on brand equity. This paper provides an insight into the various factors that influence clientele to have a favourable predisposition towards phantom brands and the influence of demographic variables towards the same. Special emphasis is also given to the growth drivers of phantom brands and the extent of clientele satisfaction towards service quality. The research design used for the study is descriptive and the sample size is restricted to 310 respondents who have preference for phantom brands and convenience sampling was used to collect the responses. Data were analysed with the help of statistical tools using SPSS. The study conveyed the fact that Clientele prefer phantom brands mainly because of the need satisfying capability at good quality and competitive pricing. Reliability and customer responsiveness are found to be significant drivers that influence customers to use phantom brands.

Keywords: Phantom Brands, Private Labels, Clientele

\section{Introduction}

Indian scenario currently is found to be highly competitive and dynamic mainly due to globalization which has given opportunity for the emergence of Private Label Brands, also termed as Phantom Brands. These brands are created and owned by channel intermediaries and are predominantly owned by powerful retailers. The power of the retailer's brand is mainly dependent on the brand equity that retailers have developed. Much emphasis is given for in store promotions and promotion through local media and the cost involved in promoting such products is far more less when compared to that of manufacturer's brands. Private labels are not only low priced but are also high on quality. Growth of organized retail chain has also facilitated the growth of private label brands in India. Consumers prefer to buy phantom brands not mainly due to its low price but because of their preference to buy products from large chain of retailers who offer a wide variety of products with better quality.

Phantom brands are commonly referred to as name brand, store brand, own label, retailer brand or generics. These are brands owned by the retailer rather than the 
producer or manufacturer. The power of such phantom brands largely depends on brand equity. Phantom brands have tremendous opportunities in India over the past few decades. Better margins and economies of scale have motivated India's big retailers to fill their shelves with their own labels by offering them at prices Indian shoppers are looking for, the value they seek in that price range and the trends they desire. India is a very different market. The predisposition that consumers have towards phantom brands is essential for the success of any retail organization as they are often designed to compete against branded products, offering customers a cheaper alternative to national brands. Initially, phantom or private label brands were viewed by the public as low-cost imitations of branded products. Phantom brands have overcome this reputation and achieved significant growth in recent years. Special consideration is given in this study to know about the influence of the various growth drivers of phantom brands from the clientele's perspective. The extent of clientele satisfaction towards service quality is also considered to be vital in attracting and retaining customers.

Due to tremendous growth potential and opportunities that prevail in the Indian scenario big retailers have started to stock shelves with their own private labels, also termed as Phantom Brands. Better margins and economies of scale are found to be the motivating and driving factors for these Brick \& Mortar retailers to have their own private labels. Phantom brands have an ability to satisfy value conscious consumers who consider both price and quality while making up the purchasing decision. Clientele today are found to be highly demanding and are looking for more variety at lower prices. This does not mean that phantom brands are sub-standard alternatives as it was considered a few years back. Such brands perform exceedingly well across various product categories as they provide good quality and competitive pricing when compared with national brands. The growth and profit potential of phantom brands in India and clientele preference for such private brands has necessitated the need for carrying out this research.

\section{Significance of the Study}

Private label brands also termed as phantom brands are widely preferred in this scenario of economic downturn based on the fact that price gains more importance as consumers increasingly turn to money-saving strategies to manage budgets. As competition is becoming stiff, retailers are working on new marketing strategies to sustain in the market, one such strategy being private branding adopted by most of the retailers. Phantom brand or Private label is one of the strategic decisions for most of the retail organizations in recent years and hence many retailers have introduced varieties of private label in different categories like apparel, food and grocery, health care, personal care, consumer durables, lifestyle etc. Major driving force behind introducing store brand is to ensure the customer store loyalty. Retailers try to implement more and more innovative ideas to gain market share over national brands. Moreover, their closeness to the clientele influences their capability to make quick adjustments to products based on customer's changing preferences. The brand name of the retailer will have more weightage on private labels. Hence, the success of phantom brands largely depends on the retailer. It is in this scenario the study has more significance in understanding the predisposition of clientele towards phantom brands. 


\section{Review of Literature}

Coelho et al. (2013) declared in their study that preference towards phantom brands termed as private labels is mainly based on the decision-making of the individual. Brands have different connotation for customers which largely influences the purchasing behaviour. Customers have a different perspective towards various brands. Private brands are found to have a significant influence on consumer perceptions based on its relative rational and emotional advantages (Vysekalová \& Mikeš, 2009). In this context Gavurová et al. (2018) state that the importance of using a social media mix for marketing purposes is supposed to have a relatively greater influence. Maisam \& Mahsa (2016) evaluated the roles of value congruity, brand love, and brand image in creating a consumer commitment that leads to positive word of mouth. Dunne \& Narasimhan (1999) reported that private labels are characterized by very weak market entry. Sutton Brady et al. (2017) emphasize the need and significance of the effect of private labels and their impact on the consumer. According to Doyle \& Murgatroyd (2011), private labels play a significant role in shaping competitive market dynamics. Private label products were primarily characterized by low quality and low cost, but the image of private label products has changed significantly over the last decade, product quality has improved, and emphasis has been placed on packaging and product design. As a result, there is a steadily growing market share of private label products (Kasotakis \& Chountalas, 2014), the largest increase is in the private label of food, which accounts for $10-45 \%$ of retail sales (Stauder et al., 2013). Katarina Valaskova, Jana Kliestikova (2018) in their study on Consumer Perception of Private Label Products attempted to determine the factors and variables that significantly influence and shape the consumer's perception and attitude towards the purchase of private label products. The study attempted to find out which types of private label products are purchased by consumers taking into consideration the various demographic characteristics as well as by the reasons for their purchase. Aja Ebeke Egele, Prince Obinna Ikechi (2017) in their study on Consumer Attitude on Private Label Brand Purchase Behaviour in Nigeria identified that consumer purchase behaviour on any private label brand is determined by the consumer purchasing experience with the store offerings. The implication of the findings is that stores must ensure that their marketing strategies achieve favourable consumer attitude to their store and they have to develop and implement consumer attitude modification strategy if they feel that consumers have an unfavourable attitude. Komal Chopra, Shouvik Dasgupta (2017) in their Study on Consumer Buying Motives for Private Labels in India has conveyed the fact that the awareness level of private label brands is high and people are aware of the existence of private labels. As per their study they also opined that there is a lot of scope for widening the market share in the Indian scenario as customers have become more and more quality and price conscious apart from preferring varieties and style. Bindubasini, S, Shakila. M.K. (2017), in their study on Private Label Brands and Store Loyalty-A Study with reference to apparels analysed the customers' perception with respect to private label brands with respect to price, quality and we could infer the relationship between these factors and their impact on the satisfaction level of the customers. The customers' satisfaction level with respect to the price and quality of the private label brands are found to be positively correlated with the satisfaction level and it is also found that gender does not have 
any influence over the satisfaction level with private label brands. Suresh Kumar (2016) in his study on Consumer's Perception on Private Label and its implication on repurchase intention in Indonesia concluded that Price, Quality, and Risk perception have strong positive influence on Private Label Intention whereas Label Loyalty has no influence but repurchase Intention it is strongly influenced by Private Label Intention. Sarah Nyengerai (2015) made a study on The Relationship between Gender, Product Category and the Constructs of Private Label Brand Perception in Zimbabwe and concluded that private label brands can be driven by ensuring high quality of packaged products which in turn will contribute to overcoming uncertainties caused by unknown brand names. It is also found that product category has an effect on perception of private label brands and retailers should understand these changes and marketing strategies should be driven based on this. Deepali Gala, Ramchandra D. Patil, (2013) made a study Consumer Attitude towards Private Labels in Comparison with National Brands and concluded that retailers are following various practices to divert the customers from national brands to private label products. The view of customers towards any purchase is dependent on the price of the product, after which the quality and availability of the product takes into account. Prasanth.M.K. Balan.J, (2013) in their study on The Consumer Perception and Rating of Private Label in The Organized Retail Chains In Kerala emphasised that brand awareness perceived quality, service level, store layout, price discounts, shelf display etc affect the consumer perception of private labels. The marketer while formulating marketing strategies can take into consideration these vital aspects which in turn will lead to potential purchase and re-purchase of store brands. Dinesh kumar, Vikkraman (2012) in their study on Customer preference for private label brands with reference to organized retail stores in Coimbatore city opined that manufacturer brand product as consumers give more importance to brand and quality, whereas private brand product consumers are more sensitive to Price and more open to trying new brands. It is also suggested that retailers should make an effort to retain the regular customers and acquire new customers by serving the upgraded private label products to them. Justin Beneke (2010) in their exploratory study on Consumer perceptions of private label brands within the retail grocery sector of South Africa investigated the perceptions of fast-moving private label brands in the South African grocery food sector. Demographic variables were largely ineffective in determining an individual's propensity to buy private label brands. However, income was found to be the most prominent of all variables, revealing a direct relationship between income and affinity towards private label brands. Mendez et al. (2008) in their research identified that price is the key variable in the brand selection. Fraser (2009) claims that consumers are influenced by the product package and they are not concerned only with the parameters of the product. In the current situation more attention is being paid to the packaging and design of products which was not actually the case in the past. This is as per the report that is given by Nair (2011) and Schiffman \& Kanuk (2010) in their studies. Amue \& Kenneth (2012) studied the influence of innovation on customer attitudes; and Ashokkumar \& Gopal (2009) described the relationship between price, quality, and risk in terms of consumer attitudes to private label products. Prior experiences of customers with private label is supposed to have a significant influence in the process of formation of the consumers' attitudes. (Kelting, et al., 2017) 


\section{Research Objectives}

- To study the influence of the various demographic variables on clientele preference towards Phantom brands

- To identify the various motivating factors that influence clientele to have a positive predisposition towards phantom brands

- To analyse the extent of retailer empowerment as a growth driver of phantom brands from the perspective of clientele

- To know about out the clientele's attitude towards service quality of phantom brands

\section{Research Hypotheses}

- H01: There is no significant difference between male and female in their preference towards phantom brands.

- H02: Age groups does not have a significant influence on Clientele's preference towards phantom brands

- H03: There is no significant relationship between clientele's shopping frequency of phantom brands and their income

- H04: There is no significant difference between the predominant motivating factors in influencing clientele to have a positive predisposition towards phantom brands

- H05: Retailer's Empowerment in promoting phantom brands follow a normal distribution

- H06: There is no significant association between availability of varieties in phantom brands and clientele need satisfaction

- H07: There is no significant difference between clientele predisposition towards service quality of phantom brands

- H08: There is no significant difference between the service quality dimensions of reliability and customer responsiveness from the clientele's perspective

\section{Research Methodology}

The research design that is used in this study is descriptive as it mainly focuses on the description of the state of affairs as it exists at present. The data for this study are both primary and secondary in nature. Sampling technique used for the study is convenience sampling which is a non - probability sampling technique. The sample size is determined as 320 through pilot study and a structured questionnaire was used to collect the response from clientele of phantom brands from prominent retail outlets. But response was only from 314 out of which 4 were found to be incomplete. Hence, the sample size was restricted to 310 . The questionnaire involved the usage of ranking and dichotomous questions, also rating scales where Likert's five-point scale was used. Both Descriptive and Inferential statistics was used for analysis. Statistical tools that were used in this study are Chi-Square Test, One Way ANOVA, Pearson's Correlation, Independent sample ' $t$ ' test, Kolmogrov-Smirnov test, Wilcoxon's Signed rank test, Friedman's test, Percentage method etc. Data was analyzed by using Statistical Package for Social Sciences (SPSS). 


\section{Analysis and Interpretation}

The study emphasises on various demographic variables and of the total sample size of 310 respondents, it is found that $62.3 \%$ of them are male and $37.7 \%$ of the respondents are female.

Table 1 Gender of the Respondents

\begin{tabular}{|l|c|c|c|}
\hline Gender & Frequency & Percentage & Cumulative Percentage \\
\hline Men & 193 & 62.3 & 62.1 \\
\hline Women & 118 & 37.7 & 100.0 \\
\hline Total & 310 & 100.0 & \\
\hline
\end{tabular}

It can therefore be inferred that majority of the respondents taken for the study are male.

Earlier research studies reveal the fact that gender has an impact on clientele perception towards phantom brands and it is also found that females perceive phantom brands to be relatively of less quality and displayed higher bias towards them. But based on this study, it has been revealed that there is no significant difference between male and female in their preference towards phantom brands which is made evident through the analysis below:

- H01: There is no significant difference between male and female in their preference towards Phantom Brands

- HA1: There is significant difference between male and female in their preference towards Phantom Brands

Table 2 Predisposition towards Phantom Brands Based on Gender

(Independent Sample 'T' Test)

\begin{tabular}{|l|c|c|c|c|}
\hline Variable & Mean & 't' value & df & Sig.(2-tailed) \\
\cline { 1 - 2 } Male & 3.37 & \multirow{2}{*}{-.109} & 308 & .911 \\
\hline
\end{tabular}

From the above Table it can be inferred that the probability value of .911 not significant as it is greater than 0.05 alpha value and therefore $\mathrm{H01}$ is accepted. It is therefore, concluded that there is no significant difference between male and female in their preference towards phantom brands which is implied from the mean values of preference of male (3.37) and female (3.38).

Table 3 Age of the Respondents

\begin{tabular}{|c|c|c|c|}
\hline Age (in years) & Frequency & Percentage & Cumulative Percentage \\
\hline $21-30$ & 117 & 37.7 & 37.7 \\
\hline $31-40$ & 117 & 37.7 & 75.4 \\
\hline $41-50$ & 41 & 13.3 & 88.7 \\
\hline$>50$ & 35 & 11.3 & 100.00 \\
\hline Total & 310 & 100.0 & \\
\hline
\end{tabular}


Age and profession were also found to affect the preference pattern and satisfaction level of respondents in respect of private label brands in different categories of products. Based on the age of the respondents in their preference towards phantom brands it is found that the distribution does not have that much of deviation which is evident from the table given below.

In the age group of 21-30 and 31-40 clientele are found to have the same extent of preference with $37.7 \%$ each and clientele in the age group of 41-50 years is relatively found to have less preference followed by clientele in the age group of above 50 years.

Table 4 Clientele's Preference towards Phantom Brands and Manufacturer's Brands

\begin{tabular}{|l|c|c|c|}
\hline \multicolumn{1}{|c|}{ Clientele's Preference } & Frequency & Valid Percentage & Cumulative Percentage \\
\hline Mostly Phantom Brands & 231 & 74.5 & 74.5 \\
\hline Mostly Manufacturer's Brands & 37 & 11.9 & 86.5 \\
\hline Equally Preferred & 42 & 13.5 & 100.0 \\
\hline Total & 310 & 100.0 & \\
\hline
\end{tabular}

From the above Table it is implied that majority of the respondents taken for the study have a positive predisposition towards phantom brands (ie) $75 \%$ while $12 \%$ of the respondents are found to have preference for mostly manufacturer's brands and around $14 \%$ of the respondents have an equal consideration for both the brands.

- H02: Age Groups do not have significant influence towards Clientele's preference towards phantom brands

- HA2: Age Groups have significant influence Clientele's preference towards phantom brands

Table 5 Influence of Age on Clientele Predisposition towards Phantom Brands (One Way Anova)

\begin{tabular}{|c|c|c|c|c|c|}
\hline Age (in years) & $\mathbf{N}$ & Mean & F value & df & Sig.(2-tailed) \\
\hline $21-30$ & 117 & 3.31 & & & \\
\cline { 1 - 3 } $31-40$ & 117 & 3.54 & \multirow{2}{*}{1.653} & 2 & \multirow{2}{*}{.193} \\
\hline$>40$ & 76 & 3.22 & & & \\
\hline
\end{tabular}

It can be inferred from the above table that the probability value of .193 is not significant as it is greater than .05 alpha value and hence, H0 is accepted. It is therefore, concluded that there is no significant difference between the various age categories of the clientele in their preference towards phantom brands. Based on Duncan's Post hoc analysis the fact is quite evident from the mean values of the various age groups of the clientele (i.e) 21-30 years (3.31), 31-40 years (3.54) and more than 40 years $(3.22)$

With growing levels of disposable income, clientele's attitude has gone for a change and they are far more open to experimentation than ever before. With the advent of modern technology, the perceptions about shopping have changed. 
Table 6 Income of the Respondents

\begin{tabular}{|c|c|c|c|}
\hline Income Level & Frequency & Valid Percentage & Cumulative Percentage \\
\hline$<15,000$ & 67 & 21.6 & 21.6 \\
\hline $16,000-25,000$ & 176 & 56.8 & 78.4 \\
\hline $26,000-35,000$ & 16 & 5.2 & 83.5 \\
\hline $36,000-45,000$ & 28 & 9.0 & 92.6 \\
\hline$>45,000$ & 23 & 7.4 & 100.0 \\
\hline Total & 310 & 100.0 & \\
\hline
\end{tabular}

When the influence of income on clientele preference towards phantom brands is analysed it is found that phantom brands are more preferred in the income range of $16,000-25,000$ and clientele in the income level of $26,000-35,000$ is found to have the least preference.

Clientele's shopping frequency in terms of once in a week, once in a fortnight, once in a month, once in six months, once in a year is analysed in terms of the various income levels. Based on chi-square test of independence attempts were made to test the relationship between the two variables.

- H03: There is no significant relationship between clientele's shopping frequency of phantom brands and their income

- HA3: There is significant relationship between clientele's shopping frequency of phantom brands and their income

Table 7 Shopping Frequency of Clientele of Phantom Brands Based on Income

\begin{tabular}{|l|c|c|c|c|c|c|}
\hline \multirow{2}{*}{ Shopping Frequency } & \multicolumn{5}{|c|}{ Income } & Total \\
\cline { 2 - 7 } & $<15,000$ & $16,000-25,000$ & $26,000-35,000$ & $36,000-45,000$ & $>45,000$ & \\
\hline Once in a week & 7 & 15 & 6 & 6 & 5 & 39 \\
\hline Once in a Fortnight & 20 & 34 & 6 & 5 & 6 & 71 \\
\hline Once in a Month & 13 & 46 & 6 & 10 & 6 & 81 \\
\hline Once in six months & 15 & 42 & 5 & 8 & 8 & 78 \\
\hline Once in a year & 5 & 20 & 6 & 5 & 5 & 41 \\
\hline Total & 60 & 157 & 29 & 34 & 30 & 310 \\
\hline
\end{tabular}

Results of Chi-Square Tests

\begin{tabular}{|l|c|c|c|}
\hline & Calculated Value & df & Sig. Value \\
\hline Pearson chi-square & 13.483 & 16 & .637 \\
\hline
\end{tabular}


It is evident that the chi-square value of 13.483 with 16 degrees of freedom is not significant. The probability value of .637 is greater than .05 level of significance and therefore, $\mathrm{H} 03$ is accepted. It is therefore concluded that there is no significant relationship between clientele's shopping frequency of phantom brands and their income.

Occupations of the respondents are also found to have a significant influence in their preference towards phantom brands. Full time salaried households are found to have more preference towards phantom brands when compared to that of other categories.

Table 8 Occupation of the Respondents

\begin{tabular}{|l|c|c|c|}
\hline \multicolumn{1}{|c|}{ Occupation } & Frequency & Valid Percentage & Cumulative Percentage \\
\hline Self Employed & 17 & 5.5 & 5.5 \\
\hline Part Time Salaried & 38 & 12.3 & 17.7 \\
\hline Full Time Salaried & 213 & 68.7 & 86.5 \\
\hline Others & 42 & 13.5 & 100.0 \\
\hline Total & 310 & 100.0 & \\
\hline
\end{tabular}

It is found from the above table that the least preference is from respondents who are self employed with $5.5 \%$ and nearly $69 \%$ of the respondents who are full time salaried individuals prefer to have phantom brands.

Special attention has been given in this study to identify the motivating factors that influence the clientele to purchase phantom brands. The various factors that have been identified through earlier researches in this regard are quality, price, variety of products available under private labels, pre-sales counselling given to the clientele, perception of clientele towards private labels as need satisfiers, discounts given, credibility the retailer's brand enjoys in the minds of the clientele etc. Respondents in the study are asked to rank the various motivating factors as per their order of preference. Hypothesis in this perspective has been tested using Friedman's test.

- H04: There is no significant difference between the predominant motivating factors in influencing clientele to have a positive predisposition towards phantom brands

- HA4: There is significant difference between the predominant motivating factors in influencing clientele to have a positive predisposition towards phantom brands

Table 9 Influence of Motivating Factors in Clientele's Predisposition towards Phantom Brands

\begin{tabular}{|l|c|}
\hline \multicolumn{1}{|c|}{ N } & \multicolumn{1}{c|}{310} \\
\hline Chi-Square & 39.184 \\
\hline df & \multicolumn{1}{c|}{6} \\
\hline Asp. Sig. & .000 \\
\hline
\end{tabular}

From the above table it can be inferred that the probability value of .000 is highly significant since it is less than 0.05 level of significance and therefore null hypothesis is rejected. It is therefore concluded that there is significant difference 
between the predominant motivating factors in influencing clientele to have a positive predisposition towards phantom brands.

Table 10 Retailer's Empowerment in Promoting Phantom Brands

\begin{tabular}{|l|c|c|}
\hline Motivating Factors & Mean & Rank \\
\hline Quality & 4.05 & IV \\
\hline Price & 3.46 & VII \\
\hline Variety & 3.82 & VI \\
\hline Pre- Sales & 4.31 & II \\
\hline Need Satisfier & 4.37 & I \\
\hline Discounts & 4.12 & III \\
\hline Credibility & 3.87 & V \\
\hline
\end{tabular}

Among the various factors that are analysed, it is evident that majority of the respondents prefer phantom brands mainly because of the fact that they are found to have a larger impact as need satisfiers followed by Pre-sales counselling which occupies the second position. Discounts, Quality, Credibility, Variety of Products under private labels occupy $3^{\text {rd }}, 4^{\text {th }}, 5^{\text {th }}$ and $6^{\text {th }}$ position respectively. Price is not found to be the major influencing factor as it occupies the last position.

Phantom brands have become more effective than classic brands and the retailers currently have plenty of opportunities to innovate and grow in ways that their previously esteemed and well-established rivals cannot. These private labels can also be much more profitable, flexible and value-creating for their owners as well as the retailers. This is because much attention is focused on the needs of the target consumer thereby leveraging the intelligence of their business loyalty cards and transactional data to understand consumer behaviours and preferences. Retailer's brands are also more promoted in tangible and innovative ways, enhancing the relevance, the value and reputation of the retailer. Moreover, private label brands have undergone more transformation in recent years and are found to be much more relevant to the current scenario besides being human and engaging.

The respondents' predisposition towards retailer's empowerment in promoting phantom brands has been analysed using kolmogrov-Smirnov test and the hypothesis have been formulated as follows:

- H05: Retailer's Empowerment in promoting phantom brands follow a normal distribution

- HA5: Retailer's Empowerment in promoting phantom brands does not follow a normal distribution

\section{One Sample Kolmogrov-Smirnov Test}

\begin{tabular}{|l|c|}
\hline \multicolumn{2}{|c|}{ Retailer Empowerment } \\
\hline N & 310 \\
\hline Mean & 3.15 \\
\hline Std. Deviation & 1.268 \\
\hline Test Statistic (K-S Test) & 2.909 \\
\hline Asp. Sig(2-tailed) & .000 \\
\hline
\end{tabular}


From the above table, it can be inferred that the probability value of .000 is highly significant as it is less than the 0.05 level of significance and hence null hypothesis is rejected and alternative hypothesis is accepted. It can therefore be concluded that retailer's empowerment in promoting phantom brands does not follow a normal distribution.

- H06: There is no significant association between availability of varieties in phantom brands and clientele need satisfaction

- HA6: There is significant association between availability of varieties in phantom brands and clientele need satisfaction

\section{Karl Pearson's Correlation Analysis}

Table 11 Association between Availability of Varieties in Phantom Brands and Clientele Need Satisfaction

\begin{tabular}{|l|c|c|}
\hline & Varieties in Phantom Brands & Clientele Need Satisfaction \\
\hline Varieties in Phantom Brands & 1 & $.000 * *(.999)$ \\
\hline Clientele Need Satisfaction & $.000 * *(.999)$ & 1 \\
\hline
\end{tabular}

Note: Values in Bracket Indicate Probability Value

From the above it can be inferred that the probability value of correlation is .999 which is greater than .05 level of significance and therefore null hypothesis is accepted. It can therefore be concluded that there is no significant association between varieties available in phantom brands and clientele need satisfaction. Further, the correlation value of .000 indicates that there is no correlation between the two variables.

Special efforts are taken to understand the clientele's predisposition towards service quality and the various attributes that are analysed in this regard are:

- Tangibles - Physical facilities of outlets, personnel, and communication materials

- Reliability-Ability to perform the promised service dependably and accurately

- Responsiveness-Willingness to help customers and provide prompt service

- Assurance-Knowledge and courtesy of employees and their ability to convey trust and confidence

- Empathy-Caring, individualized attention the firm provides its customers

- Analysis is done on the basis of Friedman's Test and the following assumptions were formulated in this regard.

H07: There is no significant difference between clientele predisposition toward service quality of phantom brands

HA7: There is significant difference between clientele predisposition towards service quality of phantom brands

\section{Friedman's Test}

\begin{tabular}{|l|l|}
\hline \multicolumn{1}{|c|}{$\mathbf{N}$} & \multicolumn{1}{c|}{$\mathbf{3 1 0}$} \\
\hline Chi-Square & 15.785 \\
\hline df & $\mathbf{4}$ \\
\hline Asymp.Sig & .003 \\
\hline
\end{tabular}


From the above table it can be inferred that the probability value of .003 is significant since, it is less than 0.05 level of significance and therefore null hypothesis is rejected. It is therefore, concluded that there is significant difference between clientele predisposition towards service quality of phantom brands.

Table 12 Clientele Predisposition towards Service Quality of Phantom Brands

\begin{tabular}{|l|c|c|}
\hline Dimensions of Service Quality & Mean & Rank \\
\hline Tangibility & 2.96 & IV \\
\hline Reliability & 3.21 & I \\
\hline Responsiveness & 3.06 & II \\
\hline Assurance & 2.79 & V \\
\hline Empathy & 2.98 & III \\
\hline
\end{tabular}

Among the various dimensions of service quality pertaining to phantom brands it is evident that majority of the respondents prefer phantom brands mainly because of its reliability with a mean score of 3.21 followed by customer responsiveness with a mean score of 3.06. Empathy and tangibility occupy the $3^{\text {rd }}$ and $4^{\text {th }}$ positions, respectively. Assurance occupies the last position.

To find out whether there are any significant differences between the clientele towards the reliability that clientele have in using phantom brands and their predisposition towards customer responsiveness of retailers Wilcoxon Signed Rank Test is used and the following hypotheses are tested:

H08: There is no significant difference between clientele predisposition towards the service quality dimensions of reliability and customer responsiveness

HA8: There is significant difference between clientele predisposition towards the service quality dimensions of reliability and customer responsiveness

\section{Wilcoxon Signed Rank Test}

\begin{tabular}{|l|c|c|c|}
\hline Service Quality Dimensions & Mean & Z & Asp. Sig.(2-tailed) \\
\hline Reliability & 3.66 & \multirow{2}{*}{-1.130} & .259 \\
\hline Customer Responsiveness & 3.60 & & \\
\hline
\end{tabular}

From the above table it can be inferred that the probability value of .259 is greater than 0.05 level of significance. Hence H08 is accepted which is a clear indication that there is no significant difference between clientele predisposition towards the service quality dimensions of reliability and customer responsiveness. The results are also authenticated from the mean values of these service quality dimensions which are more or less the same.

\section{Hypotheses Testing - Results}

H01: Accepted

H02: Accepted

H03: Accepted 
H04: Rejected

H05: Rejected

H06: Accepted

H07: Rejected

H08: Accepted

\section{Results and Discussion}

- There is no significant difference between male and female in their preference towards phantom brands which is implied from the mean values of preference of male (3.37) and female (3.38).

- Clientele are found to have more or less similar predisposition towards phantom brands irrespective of their age groups. Though Age has got a significant impact in influencing the buying behaviour of clientele the study has clearly revealed that phantom brands enjoy more or less similar popularity across all age groups. The study clearly revealed that there is no significant difference between the various age categories of the clientele in their preference towards phantom brands.

- Majority of the respondents taken for the study have a positive predisposition towards phantom brands (i.e.) $75 \%$. With the advent of modern technology, the perceptions about shopping have changed. Trust, familiarity and perceived economic situation influence customers to a very great extent to prefer phantom brands.

- $\quad$ Phantom brands are found to be more preferred in the income range of 16,000 25,000 and clientele in the income level of 26,000-35,000 is found to have the least preference. Private labels are a booming concept in the Indian retail market. It is the largest industry in India which contributes around $15 \%$ of India's GDP. Due to change in per capita income and spending, with growth in income, changing lifestyle etc. it is expected to grow $25 \%$ yearly. There is no significant relationship between clientele's shopping frequency of phantom brands and their income. It is revealed in the study that $69 \%$ of the respondents who are full time salaried individuals have a strong preference towards phantom brands.

- There is significant difference between the predominant motivating factors in influencing clientele to have a positive predisposition towards phantom brands. Phantom brands are doing exceedingly well across various product categories as they provide good quality and competitive pricing when compared with national brands. There is a lot of potential for private labels to become more broad-based in the coming years.as per the results of the study Clientele prefer phantom brands mainly because of the fact that they are found to have a larger impact as need satisfiers which is ranked $1^{\text {st }}$ followed by Pre-sales counselling which occupies the second position.

- Retailer's empowerment in promoting phantom brands does not follow a normal distribution.

- There is no significant association between varieties available in phantom brands and clientele need satisfaction and the correlation value is 0

- There is significant difference between clientele predisposition towards service quality of phantom brands. Majority of the respondents prefer phantom brands 
mainly because of the reliability they have in using phantom brands which is evident from the mean score of 3.21 and it is ranked $1^{\text {st }}$ followed by customer responsiveness with a mean score of 3.06. There is no significant difference between clientele predisposition towards service quality dimensions of reliability and customer responsiveness.

\section{Conclusion}

The agile nature of phantom brands also termed as private labels, has created lot of opportunities for Indian retailers by helping them to tap the market potential by understanding the needs of the clientele that arise from emerging trends. Retailers today have recognized that profit margins on products designed and sourced by them are significantly higher than on branded products. Once phantom brands were perceived as cheaper and 'me-too' products. But their growth is considered to be relatively more tremendous over the recent years. They stand at par with that of renowned manufacturer's brands in terms of quality, variety, discounts, need satisfying capability etc. Retail outlets have the unique advantage of constant, live interaction with its consumers and therefore enable it to gather instant feedback and understand what drives consumers towards a brand/product in a particular region or country. Since, more focus and attention is given to the clientele by means of offering the private labels in the way that is preferred by the customers, phantom brands in the current scenario is found to have an edge over their competitive counterparts. Phantom brands today are viewed as good quality, value-for-money choices. Retailers have well understood the monetary benefits of creating private labels since they are well aware of the Indian customer's taste, preferences, economic background and other crucial factors that determine the buying behaviour. Phantom brands in India are not perceived as cheap or low-quality alternatives. Besides, better margins and higher returns on shelf space, phantom brands have enhanced the overall brand equity of retail stores.

\section{References}

1. Valaskova, K., Kliestikova, J., Krizanova, A., "Consumer Perception of Private Label Products: An Empirical Research" Journal of Competitiveness, 10(3), 149-163. https://doi.org/10.7441/joc.2018.03.10

2. Bindubasini.S, Shakila.M.K., "Private Label Brands and Store Loyalty- A Study with reference to apparels" International Journal of Management Studies ISSN(Print) 2249-0302 ISSN (Online)2231-2528, Vol-IV, Special Issue-3, November 2017, pp.61-76

3. Aja Ebeke Egele, Prince Obinna Ikechi, "The Influence of Consumer Attitude on Private Label Brand Purchase Behavior in Port Harcourt, Rivers State, Nigeria”, IOSR Journal of Humanities and Social Science (IOSR-JHSS), Volume 22, Issue 8, Ver. 12 (August. 2017) PP 58-70 p-ISSN: 2279-0845.

4. Komal Chopra, Shouvik Dasgupta, "Study of Consumer Buying Motives for Private Labels in India", International Journal of Engineering and Management Research, Volume-7, Issue-1, January-February 2017, ISSN (ONLINE): 22500758, ISSN (PRINT): 2394-6962, pp.116-120. 
5. Kelting, K., Duhachek, A., \& Whitler, K. (2017). Can copycat private labels improve the consumer's shopping experience? A fluency explanation. Journal of the Academy of Marketing Science, 45 (4), 569-585. https://doi.org/0.1007/s11747-017-0520-2

6. Suresh Kumar, "Consumers' Perception towards Private Label and its Implication on Repurchase Intention: A Case of Giant's Customers in Cikarang, Indonesia", International Journal of Managerial Studies and Research (IJMSR) Volume 4, Issue 5, May 2016, PP 94-99 ISSN 2349-0330 (Print) \& ISSN 23490349 (Online) http://dx.doi.org/10.20431/2349-0349.0405012

7. Sarah Nyengerai, "The Relationship between Gender, Product Category and the Constructs of Private Label Brand Perception in Zimbabwe", International Journal of Science and Research (IJSR) ISSN (Online): 2319-7064 Index Copernicus Value (2013): 6.14 | Impact Factor (2014): 5.611 Volume 4 Issue 10, October 2015, pp.2093-2096

8. Thanasuta, K. (2015). Thai consumers' purchase decisions and private label brands. 25. 26. 27. 28. 29. 30. 31. 32. 33. 34. 35. 36. 37. 38. 39. 40. 41. joc32018-v3b.indd 162 30.9.2018 21:57:35 163 International Journal of Emerging Markets, 10 (1), 102-121. https://doi.org/10.1108/IJOEM-02- 2011-0016

9. Deepali Gala, Ramchandra D. Patil, "Consumer Attitude towards Private Labels in Comparison with National Brands", International Journal of Business and Management Invention ISSN (Online): 2319 - 8028, ISSN (Print): 2319 - 801X www.ijbmi.org Volume 2 Issue 5 || May. 2013\| PP.12-18

10. Prasanth M.K., Balan.J, "The Consumer Perception And Rating Of Private Label In The Organized Retail Chains In Kerala" International Journal of Engineering Research \& Technology (IJERT)Vol. 2 Issue 1, January- 2013, ISSN: 2278-0181, pp.1-11.

11. Ramakrishnan, Sudharani Ravindran, “A Study On The Consumer Perception Towards Private Label Brands With Special Reference To Big Bazaar, Coimbatore, Tamil Nadu", Journal of Arts, Science \& Commerce, Vol.- III, Issue -3(3),July 2012 [79]Pp 79-85

12. U. Dineshkumar and P. Vikkraman, "Customer preference for private label brands with reference to organized retail stores in Coimbatore city" , Elixir International Journal,ISSN:2229-712X, 10784-10787

13. Justin Beneke, "Consumer perceptions of private label brands within the retail grocery sector of South Africa", African Journal of Business Management, Vol. 4(2), pp. 203-220, February 2010

14. ISSN $1993-8233$

15. Rimarčík M. (2007). Štatistika pre prax. Bratislava: Vydavatel'stvo: Marián Rimarčík. Schiffman L. G. \& Kanuk L. L. (2010). Consumer Behavior. New Jersey: Prentice Hall.

16. Stauder, M., Kurthy, G., \& Juhasz, A. (2012). Private labels in the strategy of food producers and retailers. In P.J. Batt (Ed.), IV International Symposium on Improving the Performance of Supply Chains in the Transitional Economies (pp. 343-348). 
17. Budapest (Hungary): Rest. Inst. Agr. Econ. Sutton-Brady C., Taylor T., \& Kamvounias P. (2017). Private label brands: a relationship perspective. Journal of Business \& Industrial Marketing, 32 (8), 1051-1061. https://doi. org/10.1108/JBIM-03-2015-0051

18. Svoboda, R., \& Kopecka, L. (2017). The Sweezy model of price competition among private labels of chain stores. Agricultural Economics - Zemědelská ekonomika, 63(7), 299-307. https:// doi.org/10.17221/355/2015-AGRICECON

19. Vysekalová, J. \& Mikeš, J. (2009). Image a firemná identita. Praha: Grada Publishing a.s.

20. Wyma, L., van der Merwe, D., Erasmus, A. C., Bosman, M. J. C, Steyn, F., \& Strydom, H. (2014). Consumers' preferences for various private label and national brand food products at different retailers in Potchefstroom, South Africa. In J. C. GazquezAbad, et al. (Eds.), Proceeding on National Brands and Private Labels in Retailing (pp. 121-130).

21. Cham (Vysekalová, J. \& Mikeš, J. (2009). Image a firemná identita. Praha: Grada Publishing a.s

22. Grohmann B., Spangenberg E. R., \& Sprott D. E. (2007). The influence of tactile input on the evaluation of retail product offerings. Journal of Retailing, 83 (2), 237-245. https://doi. org/10.1016/j.jretai.2006.09.001

23. Horáková, M. (2015). Consumer Behavior of College Students in the Czech Republic. Journal of Competitiveness, 7 (4), 68-85. http://doi.org/10.7441/joc.2015.04.05

24. Kakkos, N., Trivellas, P., \& Sdrolias, L. (2014). Identifying drivers of purchase intention for private label brands. Preliminary evidence from Greek consumers. In A. Kavoura, D.P. Sakas, P. Tomaras (Eds.), Proceedings of the 3rd International Conference on Strategic Innovative Marketing (pp. 522-528). Larisa (Greece): Technol. Educ. Inst. Thessalia. https://doi.org/10.1016/ j.sbspro.2015.01.1232

25. Kantar Tns. (2015). Oblúbenost' privátnych značiek na Slovensku rastie. Retrieved May 17, 2018, from: http://www.tns-global.sk/informacie-prevas/tlacove-spravy/oblubenostprivatnych-znaciek-na-slovensku-rastie.

26. Kasotakis, D. \& Chountalas, P. (2014). Consumer attitudes towards private label products: An empirical investigation. Proceedings of the eRA9 International Scientific Conference (pp. 18-26). Piraeus (Greece): Technol. Educ. Inst. Piraeus

\section{Web links}

- $\quad$ www.cjournal.cz

- www.researchjournals.com.

- www.elixirpublishers.com

- www.iosrjournals.org

- www.ijemr.net

- www.ijbmi.org

- www.academicjournals.org

- www.researchersworld.com/ijms/

- www.ijsr.net

- www.arcjournals.org

- www.ijert.org 


\section{About Our Authors}

M. Beulah Viji Christiana Professor in the Department of Management Studies, Panimalar Engineering College affiliated to Anna University, has a got a rich teaching experience which spans over 20 years. She is an experienced and innovative student focused professional and mentor with a proven track record of excellent teaching skills. Her academic qualification encompasses Post Graduate degrees in English Literature and Business Administration from Madurai Kamaraj University and M. Phil in Management Studies from Bharathidasan University. She was awarded Ph.D. in Management Studies from Mother Teresa Women's University, Kodaikanal in 2012. She has published more than 40 research articles in various national and international journals of repute including Scopus indexed journals and has a record of active participation in Professional workshops as well as in conferences. Besides, she is also known for her role as a reviewer in various journals and books and she has authored four books titled "Strategic Stress Management of Gold Collars", "Principles of Management", "Organizational Behaviour" and "Strategic Management".

M. Joseph Sasi Rajan an engineer by profession has donned various roles in his career as Software Developer, Team Lead, QA Lead, Scrum Master etc in I.T Arena. His area of expertise is in design and development of quality standards in delivery of products and services which matches international standards. His passion for the same can be revealed through his holding of Professional Certification in Lean Six Sigma Green Belt, Black Belt \& Scrum Master. His academic qualification records a B.E degree in ECE from Madurai Kamaraj University and MBA in Technology Management from Anna University and his work experience spans around 16 years. He has published various research papers in national and international journals of repute and has also an active participation in various Professional workshops. 